\title{
Self-assembled $\beta$-lactoglobulin-conjugated linoleic acid complex for colon cancer-targeted substance
}

\author{
H. R. Jiang and N. Liu ${ }^{1}$ \\ Key Laboratory of Dairy Science, Ministry of Education, College of Food Science, Northeast Agricultural University, 59 Mucai Street, \\ Xiangfang District, Harbin 150030, China
}

\begin{abstract}
$\beta$-Lactoglobulin $(\beta-\mathrm{LG})$ is a member of the lipocalin protein family and can bind a variety of hydrophobic molecules, such as fatty acids, in vitro. In this study, a potential colon-targeted antitumor drug was developed using bovine $\beta-\mathrm{LG}$ as a carrier loaded with cis-9, trans-11 conjugated linoleic acid (CLA). The intrinsic tryptophan fluorescence intensity of $\beta-\mathrm{LG}$ monitored by spectrofluorometer showed that $2.46 \mathrm{~mol}$ of CLA can be bound per mole of $\beta$-LG. Dynamic light scattering showed the formation of a $\beta$-LG-CLA self-assembled complex with particle size of $170 \pm 0.08 \mathrm{~nm}$. After treatment with gastrointestinal $\mathrm{pH}$ and digestive enzymes, $\beta$-LG-CLA complex showed very good stability in gastrointestinal conditions in vitro, measured by zeta potential analyzer and sodium dodecyl sulfate PAGE, respectively. In an intestinal model in vitro, the concentration of CLA in Caco-2 cells was detected by reverse-phase HPLC, and the level of CLA in cells after treatment with $\beta$-LG-CLA complex was significantly greater than after treatment with CLA, which means $\beta-L G$ served as a capsular vehicle of CLA for intracellular transport. According to cell proliferation assay, $\beta$-LG-CLA complex can inhibit the viability of Caco2 cells, and the inhibition rate is significantly greater than with the same concentration of CLA $(100 \mu M)$. The study revealed that bovine $\beta-\mathrm{LG}$ as a carrier binding with CLA can potentially be used for colon cancer therapy.
\end{abstract}

Key words: beta-lactoglobulin, conjugated linoleic acid, colon cancer, targeted substance

\section{INTRODUCTION}

Bovine $\beta$-LG, with an 18.4-kDa molecular mass for the monomer and $162 \mathrm{AA}$ residues, is the major whey protein in cow's milk, and its properties have been stud-

Received January 10, 2010.

Accepted March 28, 2010.

${ }^{1}$ Corresponding author: ningliu6666@yahoo.com.cn ied extensively (Pervaiz and Brew, 1985). The secondary structure of $\beta$-LG has been reported: an 8 -stranded antiparallel $\beta$-barrel forms a conical central calyx, with a 3 -turn $\alpha$-helix on the outer surface of the $\beta$-barrel and a ninth $\beta$-strand flanking the first strand (Papiz et al., 1986; Brownlow et al., 1997). The central cavity of $\beta$-LG provides a ligand-binding site for hydrophobic molecules, and this special property makes $\beta-\mathrm{LG}$ a core member of the lipocalin family, which shows a variety of biological functions related to the binding and transport of metabolites (Flower, 1994). It has been reported that $\beta$-LG has an observable affinity for retinol (Futterman and Heller, 1972) and many fatty acids, such as palmitic acid (Wu et al., 1999; Ragona et al., 2000), n-3 polyunsaturated fatty acids (Zimet and Livney, 2009), conjugated linoleic acid (CLA), and myristic acid (Considine et al., 2007), and in cow's milk, the main ligands that have been found to bind to $\beta$-LG are fatty acids (Pérez and Calvo, 1995). Therefore, it is likely possible to make a self-assembled complex by bovine $\beta$-LG binding cis-9, trans-11 CLA (c9,t11-CLA).

Conjugated linoleic acid was originally described as an anticarcinogen isolated from grilled ground beef (Ha et al., 1987). As positional and geometric isomers of linoleic acid that have conjugated double bonds, several isomers of CLA have been identified. It has been found that ruminant dairy products are good sources of CLA isomers, especially $c 9, t 11$-CLA (Kay et al., 2004). Many publications have reported CLA isomers altering carcinogenesis, with the main focus on 2 major forms: $c 9, t 11-C L A$ and trans-10, cis-12 CLA (t10,c12-CLA). However, the growth inhibitory effects of CLA isomers varied with the model used, such as mammary, colon, and stomach cancer in vitro and in vivo, and different CLA isomers act through different mechanisms of inhibiting tumor growth (Kelley et al., 2007). There are very few studies of $c 9, t 11$-CLA in inhibiting cell growth of colon, colorectal cell lines, and more studies are needed to determine a preferable concentration of CLA during antitumor treatment.

Colorectal cancer is the third most common cause of cancer-related death worldwide (Parkin et al., 2005). Finding an effective therapeutic approach for colorectal 
cancer is very important to inhibit the rate of recurrence. A colon-specific drug-delivery system has the potential to cure bowel disease, including colorectal cancer (Zhao et al., 2008). Because the physiological conditions along the gastrointestinal tract include various enzymes and drastic changes in $\mathrm{pH}$, which make the drugs likely to be absorbed or degraded before reaching colon, a special dosage form is required for the oral colon-specific drug-delivery system to the colon. It has been reported that $\beta-\mathrm{LG}$ can resist digestive enzyme hydrolysis in the gastrointestinal tract (Reddy et al., 1998) and remain intact while reaching the upper portion of the small intestine. In addition, $\beta-\mathrm{LG}$ is stable in low-pH conditions and could play a protective role for bound ligands in the acidic conditions of the stomach (Papiz et al., 1986). Thus, to some extent, $\beta$-LG has the ability to be a coating for CLA delivery to the colon.

In the present research, we synthesized a self-assembled $\beta$-LG-CLA complex beyond the hydrophobic ligand binding property of bovine $\beta$-LG, observed its stability in gastrointestinal conditions, detected the absorption level of CLA in the colon model after treatment with $\beta$-LG-CLA complex, and measured the inhibition effect of $\beta$-LG-CLA complex on colon cancer to evaluate whether this self-assembled complex has the potential to be a colon-specific drug for antitumor application in colon carcinoma.

\section{MATERIALS AND METHODS}

\section{Materials}

Bovine $\beta$-LG A was purchased from Sigma Chemical Company (St. Louis, MO), and the purity was $>99 \%$. The $c 9, t 11-C L A$ was purchased from Cayman (Ann Arbor, MI), and the purity was $>98 \%$. Human colon tumor cancer Coca-2 cells were obtained from Cell Bank, Chinese Academy of Science (Shanghai, China). The 24-well and 96-well plates and a 6-well transwell plate were purchased from Corning Costar Corporation (Cambridge, MA). Pepsin and trypsin; Dulbecco's modified Eagle's medium (DMEM) and fetal bovine serum for cell culture; and acetonitrile, methanol, ethyl acetate, and acetic acid for reverse-phase HPLC (RP-HPLC) were all purchased from Sigma Chemical Company.

\section{Preparation of $\beta$-LG-CLA Complex}

The $\beta$-LG-CLA was synthesized beyond the hydrophobic ligand binding property of bovine $\beta$-LG (Wu et al., 1999; Ragona et al., 2000; Kontopidis et al., 2004) with a titration experiment for $c 9, t 11$-CLA binding to bovine $\beta$-LG. Intrinsic fluorescence of the tryptophan residues of bovine $\beta$-LG was measured before and after the addition of different amounts of CLA, which was predissolved in ethanol $(10 \mathrm{mg} / 100 \mu \mathrm{L})$, to $1 \mu M$ bovine $\beta$-LG solution. The CLA added ranged from 2 to $12.4 \mu \mathrm{L}$ with 2 incremental aliquots, and bovine $\beta$-LG was dissolved in $2.5 \mathrm{~mL}$ of $100 \mathrm{~m} M$ Tris- $\mathrm{HCl}$ buffer solution with a $\mathrm{pH}$ of 7.0. After vigorous stirring, the $\beta$-LG-CLA mixtures (molar ratio range from 1:1 to 1:3) were incubated for $10 \mathrm{~min}$ at room temperature before the measurements. The binding parameters were studied by measuring the binding-induced quenching of the intrinsic Trp 19 fluorescence of the protein, using a fluorescence spectrofluorometer (Hitachi, Tokyo, Japan), at excitation and emission wavelengths of 279 and $332 \mathrm{~nm}$, respectively (Christiaens et al., 2002). Measurements were performed in triplicate. The number of CLA molecules involved in binding per $\beta$-LG molecule was calculated by fluorescence intensity, expressed as the percentage of the initial fluorescence of CLA-free $\beta$-LG versus that with the added CLA concentration. The raw data were analyzed according to the model described by Christiaens et al. (2002). After the suitable binding molar ratio between $\beta-\mathrm{LG}$ and CLA was obtained, the $\beta$-LG-CLA complex was prepared by the titration experiment mentioned earlier, and the particle size at pH 7.0 was measured by dynamic light scattering using a Delsa Nano $\mathrm{C}$ particle size and zeta potential analyzer (Beckman Coulter, Brea, CA). Then, $\beta$-LG-CLA complex was synthesized and stored with $0.1 \%$ Tween 40 to keep a micelle state for the following research.

\section{Stability of $\beta-L G-C L A$ in the Gastrointestinal System}

The stability characteristics of $\beta$-LG-CLA were considered by electrophoretic mobility under a wide range of physical $\mathrm{pH}$ conditions, and the degree of digestion with various digestive enzymes in vitro was also studied. To investigate the stability of $\beta$-LG-CLA under stomach and intestinal $\mathrm{pH}$-value conditions, the complex solutions contained were titrated at $\mathrm{pH}$ 1.0, 1.2, $1.4,1.8,2.4,2.8$, and 3.0 to imitate the acidic environment of the stomach and $\mathrm{pH} 6.0,6.2,6.4,6.8,7.0,7.2$, and 7.4 to imitate the intestinal environment. A zeta potential analyzer (Delsa Nano C, Beckman Coulter) was used under a $3-\mathrm{V} / \mathrm{cm}$ electric field at $25^{\circ} \mathrm{C}$ to detect the electrophoretic mobility of the complex.

To investigate the stability of $\beta$-LG-CLA in the presence of digestive enzymes, pepsin and trypsin were used as digestive enzymes. The in vitro digestion experiments were performed at $37^{\circ} \mathrm{C}$ with an enzyme-substrate ratio of 1:100 (wt/wt) using $0.5 \mathrm{mg} / \mathrm{mL}$ enzyme and 5 $\mathrm{mg} / \mathrm{mL}$ protein solutions. The $\mathrm{pH}$ for pepsin digestion was titrated at 1.2 using $1 \mathrm{~mol} / \mathrm{L} \mathrm{HCl}$, and for trypsin 
digestion, the $\mathrm{pH}$ was titrated at 8.0 using $1 \mathrm{~mol} / \mathrm{L}$ $\mathrm{NaOH}$. Mixtures were stirred gently during digestion, and aliquots were withdrawn at $0,5,10,15,20,25,30$, 60, 90, and $120 \mathrm{~min}$. The samples were immediately frozen at $-80^{\circ} \mathrm{C}$ for $20 \%$ SDS-PAGE analysis. The time-dependent proteolysis of $\beta$-LG-CLA complex under digestive enzymes was expressed by the intensities of protein bands in gel.

\section{Cell Culture and In Vitro Intestinal Model Establishment}

Caco-2 cells were grown on a 24 -well plate with 1.0 $\times 10^{4}$ cells/well in the presence of DMEM containing $20 \%$ fetal bovine serum, $2 \mathrm{mmol} / \mathrm{L}$ of L-glutamine, 100 $\mathrm{U} / \mathrm{mL}$ of penicillin, and $100 \mu \mathrm{g} / \mathrm{mL}$ of streptomycin. The cell cultures were maintained at $37^{\circ} \mathrm{C}$ in a humidified atmosphere of $5 \% \mathrm{CO}_{2}$. After $72 \mathrm{~h}$ of incubation, cells were seeded in a 6 -well transwell plate with $1.0 \times$ $10^{5}$ cells/well. After $6 \mathrm{~d}$, the in vitro intestinal model had been established, and the permeability of each cell monolayer was tested following the method of During and Harrison (2005). Briefly, at the beginning of the test, the apical side received $2 \mathrm{~mL}$ of serum-free DMEM containing $100 \mu M$ CLA or $\beta$-LG-CLA kept in $0.1 \%$ Tween 40, respectively, and the basolateral side received $2 \mathrm{~mL}$ of serum-free medium. After $4 \mathrm{~h}$ of incubation at $37^{\circ} \mathrm{C}$, the cell monolayer was washed with PBS 3 times and collected for analysis of CLA by RP-HPLC.

\section{Cell Proliferation Assay}

The influence of $\beta$-LG-CLA complex on the viability of Caco-2 cells was determined by methyl thiazolyl tetrazolium assay. Briefly, the cells were seeded in 96-well plates with $1.0 \times 10^{5}$ cells/well, which, after $24 \mathrm{~h}$ of incubation, were transferred to another culture medium containing $100 \mu M \beta$-LG, $100 \mu M$ CLA, and $100 \mu M$ $\beta$-LG-CLA. Because the CLA was dissolved with ethanol, the same amount of ethanol contained in DMEM was used as an ethanol control group. Cells cultured with DMEM with $20 \%$ fetal bovine serum were used as control. For each treated group, 3 replicates were employed. The cells were separately incubated for 0 , 24, 48, and $72 \mathrm{~h}$. At different intervals, one plate was tested. Fifteen microliters of $5 \mathrm{mg} / \mathrm{mL}$ methyl thiazolyl tetrazolium solution in PBS was added to each well and incubated for $4 \mathrm{~h} ; 150 \mu \mathrm{L}$ of dimethyl sulfoxide was added to each well after removing the medium. The plates were shaken for $10 \mathrm{~min}$ and then read at $570 \mathrm{~nm}$ in a Bio-Rad 680 ELISA reader (Bio-Rad Laboratories, Hercules, CA). The inhibitory rate was calculated using the following equation: Inhibitory rate $(\%)=\left(\mathrm{OD}_{\text {control }}\right.$ $\left.-\mathrm{OD}_{\text {treatment }}\right) \times 100 \%$, where OD $=$ optical density.

\section{RP-HPLC for CLA in Caco-2 Cells}

Absorption of CLA in the intestinal model in vitro was detected by RP-HPLC. The methods for CLA extraction from the Caco-2 cell monolayer and determination of the CLA level in cells were described by Li et al. (2001). Briefly, the separation was performed on a C18 column $(0.46 \mathrm{~cm} \times 25 \mathrm{~cm})$ with a particle size of $5 \mu \mathrm{m}$ and pore size of $300 \AA$ (Shiseido, Tokyo, Japan) kept at $25^{\circ} \mathrm{C}$; the detection wavelength was $195 \mathrm{~nm}$. Eluant A was $25 \%$ HPLC-grade acetonitrile and $75 \%$ water, containing $0.12 \%$ acetic acid; eluant B was HPLC-grade acetonitrile containing $0.12 \%$ acetic acid. The elution gradient was set as follows: $0 \sim 70$ min changes from 100 to $\sim 12.5 \%$ A, $70 \sim 80$ min changes from 12.5 to $\sim 100 \%$ A. The flow rate was $1 \mathrm{~mL} / \mathrm{min}$.

\section{Statistical Analysis}

All data detected were analyzed by Statistix 8.0 software; $P$-values $<0.05$ were considered significant. Data were reported as mean \pm standard deviation. Each value is the mean of at least 3 repetitive experiments in each group.

\section{RESULTS}

\section{Synthesis of $\beta-L G-C L A$ Complex}

The $\beta$-LG-CLA complex was prepared by the titration experiment. The number of CLA binding to bovine $\beta-\mathrm{LG}$ was measured by the binding-induced quenching of intrinsic fluorescence of tryptophanyl residue Trp 19 of $\beta$-LG. The binding constant $\mathrm{K}_{\mathrm{b}}$ was analyzed according to the model derivation used by Christiaens et al. (2002). As the concentration of CLA added in bovine $\beta$-LG solution increased, the fluorescence intensity decreased gradually (Figure 1). The analysis suggested that $2.46 \pm 1.05 \mathrm{~mol}$ of CLA were bound per mole of $\beta$-LG; $K_{b}=3.7 \times 10^{6} M^{-1}$. Therefore, $\beta$-LG-CLA complex was synthesized in the solution containing CLA: $\beta-$ LG with a molar ratio of 2.46:1 CLA: $\beta-L G$. Particle size of $\beta$-LG-CLA complex at pH 7.0 was measured by dynamic light scattering. As shown in Figure 2, $\beta$-LGCLA complex exhibits a narrow size distribution with an average diameter of around $171.8 \mathrm{~nm}$ (peak value $197.7 \mathrm{~nm}$, polydispersity index 0.181 ), which means that $\beta$-LG-CLA complex is a microsized compound. After 3 parallel tests of $\beta$-LG-CLA complex for particle size, we got the final diameter result of $170.7 \pm 0.08 \mathrm{~nm}$.

\section{Stability of $\beta$-LG-CLA Complex in Gastrointestinal pH Conditions}

The stability of $\beta$-LG-CLA complex in gastrointestinal $\mathrm{pH}$ conditions was monitored using a zeta potential 


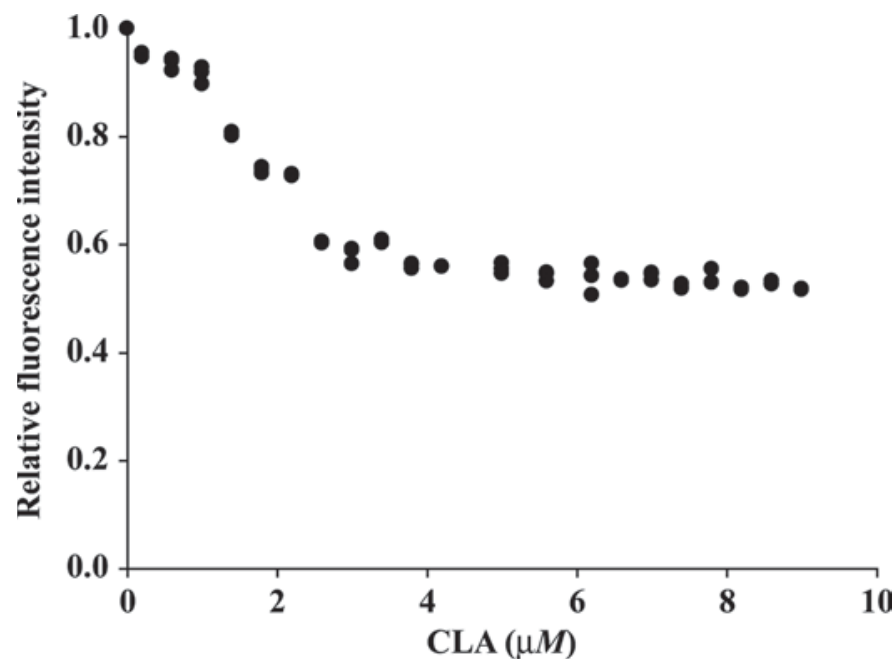

Figure 1. Spectrofluorometric analysis of the binding of cis-9, trans-11 conjugated linoleic acid (CLA) to bovine $\beta$-LG at $\mathrm{pH} 7.0$ and $25^{\circ} \mathrm{C}$. The symbols represent experimental points of triplicate titration runs.

analyzer. Freshly prepared $\beta$-LG-CLA complex at $\mathrm{pH}$ 7.0 had a zeta potential of $-47.62 \pm 0.02 \mathrm{mV}$ (Figure $3)$. To investigate the stability of $\beta$-LG-CLA under stomach and intestinal $\mathrm{pH}$ value conditions, $\mathrm{NaOH}$ and $\mathrm{HCl}$ were added, respectively, to shift the $\mathrm{pH}$ drastically to imitate the stomach $\mathrm{pH}$ range from 1.0 to 3.0 , the distal-end of the colon $\mathrm{pH}$ of 6.0 to 6.4 , and the proximal end of the colon $\mathrm{pH}$ of 7.0 to 7.4. The zeta potential of $\beta$-LG-CLA complex reduced from $37.25 \pm$ $2.40 \mathrm{mV}$ to $18.48 \pm 2.46 \mathrm{mV}$ as the $\mathrm{pH}$ increased from 1 to 3 , with the point of zero net charge at $\mathrm{pH} 5.12$. As the $\mathrm{pH}$ increased from 6.0 to 7.4 , the zeta potential of $\beta$-LG-CLA complex changed into negative values from $-44.01 \pm 2.26 \mathrm{mV}$ to $-47.47 \pm 2.45 \mathrm{mV}$, and when

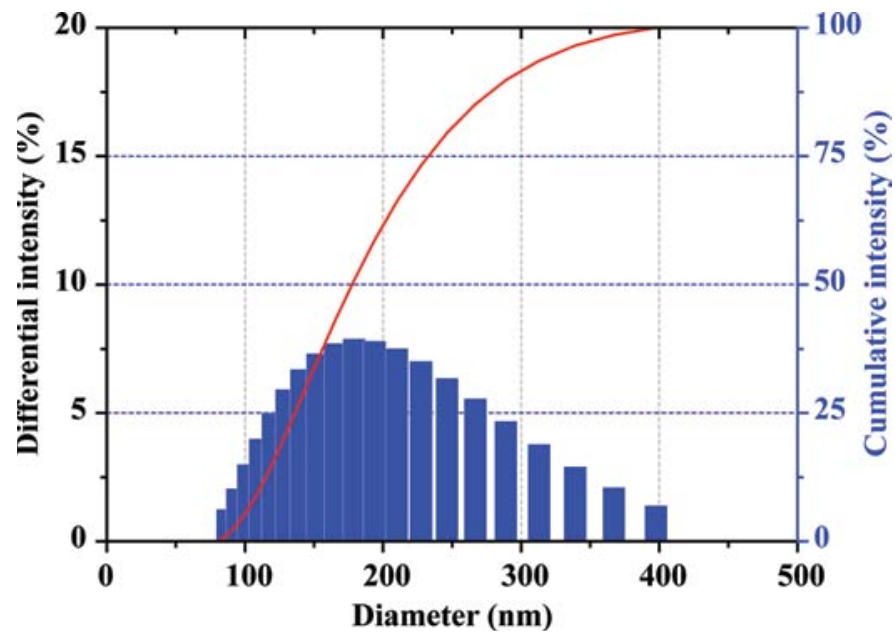

Figure 2. Particle size distribution of $\beta-\mathrm{LG}-$ conjugated linoleic acid complex at $\mathrm{pH} 7.0$ and $25^{\circ} \mathrm{C}$. Color version available in the online PDF. the $\mathrm{pH}$ increased to 8.0 , the zeta potential changed to $-51.41 \pm 3.40 \mathrm{mV}$.

\section{In Vitro Digestibility of $\beta-L G-C L A$ Complex by Digestive Enzymes}

The stability of $\beta$-LG-CLA complex in gastrointestinal conditions was also investigated under the function of digestive enzymes and shown by SDS-PAGE (Figure $3)$. In the $\beta$-LG-CLA complex-pepsin mixture, there were 3 major bands in the gel (Figure 4A). The intensity of the $\beta-\mathrm{LG}$ band (Figure $4 \mathrm{~A}$, band $\mathrm{b}, 18.4 \mathrm{kDa}$ ) reduced gradually with the simultaneous appearance of the other band (Figure 3A, band c, 10 to $\sim 17 \mathrm{kDa}$ ). The intensity of band a (Figure $4 \mathrm{~A}, \sim 36 \mathrm{kDa}$ ) appeared to decrease slowly during the 2 -h incubation period, but the tendency was not significant. The intensity of band c seems to have been the same from 0 to $60 \mathrm{~min}$ but decreased significantly from 60 to $120 \mathrm{~min}$ of incubation. In the $\beta$-LG-CLA complex-trypsin mixture, there were also 3 major bands in the gel (Figure 4B). Band $\mathrm{b}$, which represents the $\beta$-LG monomer, is similar to the pattern in the gel of the $\beta$-LG-CLA complex-pepsin mixture; however, the intensity of band a (Figure 4B, $\sim 36 \mathrm{kDa}$ ) appeared to increase up in 120 min of incubation. Band c (Figure 4B, 10 to $\sim 17 \mathrm{kDa}$ ) appeared and separated from band b slowly from 0 to $30 \mathrm{~min}$, and the intensity decreased significantly from 60 to $120 \mathrm{~min}$ of incubation.

\section{Intestinal Absorption of CLA from $\beta$-LG-CLA Complex}

The Caco- 2 cells were cultured to mimic the bowl model in vitro for investigating intestinal absorption of

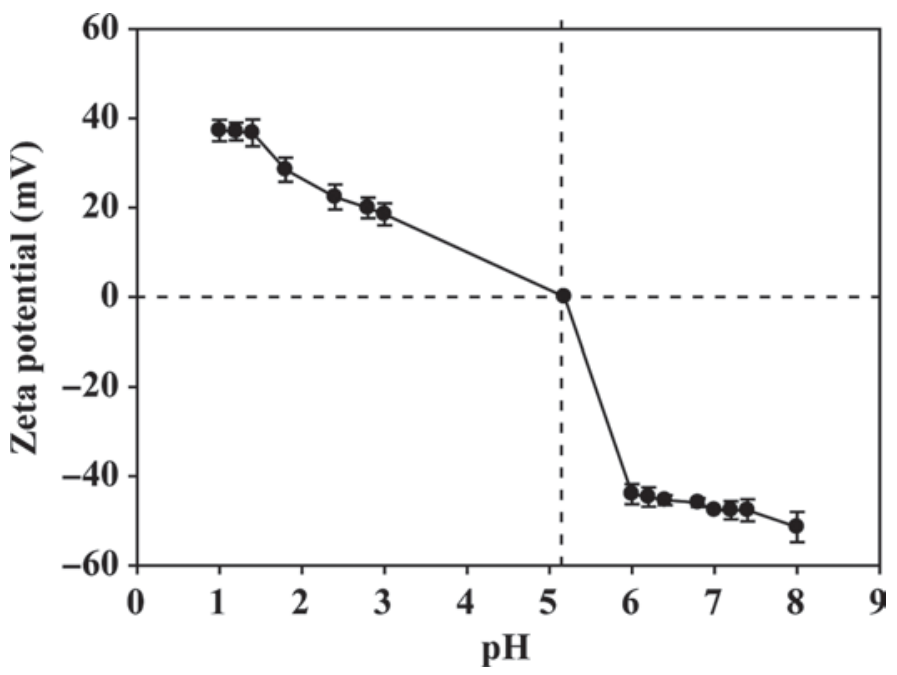

Figure 3. Zeta potential of $\beta$-LG-conjugated linoleic acid complex as a function of $\mathrm{pH}$ in gastrointestinal conditions. 

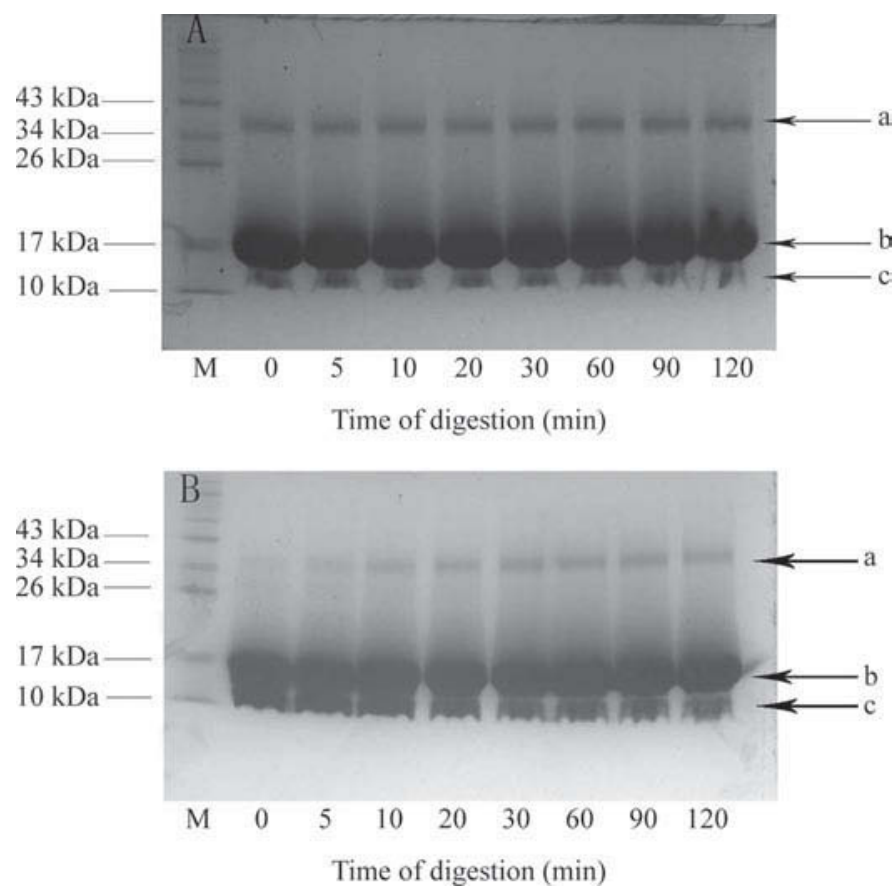

Figure 4. The SDS-PAGE patterns obtained from $\beta$-LG-conjugated linoleic acid (CLA) complex solution as a function of digestive enzymes. A) The continuous phase of $\beta$-LG-CLA complex treated by pepsin in $2 \mathrm{~h}$; B) the continuous phase of $\beta$-LG-CLA complex treated by trypsin in $2 \mathrm{~h}$. Bands a, b, and c are 3 major bands that appeared in the SDS-PAGE during gastrointestinal digestion. The molecular weight of a is about $36.8 \mathrm{kDa}$, b is about $18.4 \mathrm{kDa}$, and $\mathrm{c}$ is about 10 to $16 \mathrm{kDa} . \mathrm{M}=$ molecular weight marker.

CLA from $\beta$-LG-CLA complex. Cells were incubated with 100- $\mu M c 9, t 11$-CLA isomer or $\beta$-LG-CLA complex loading 100- $\mu M c 9, t 11$-CLA isomer for $4 \mathrm{~h}$. The extent of absorption of $c 9, t 11$-CLA through Caco-2 cells was analyzed by RP-HPLC. To quantify $c 9, t 11$-CLA level, the correlation between the peak area and the injection quantity for $c 9, t 11$-CLA standard was obtained by linear regression. In our experiment, the linearity of the standard curves was $\mathrm{y}=3.4 \mathrm{E}+07 \mathrm{x}+1.1 \mathrm{E}+5$, with a correlation coefficient $\left(\mathrm{R}^{2}\right)$ value of 0.998 . Compared with the peak area of $100-\mu M c 9, t 11$-CLA (Figure 5A), the data (Figure 5) showed that the level of $c 9, t 11$-CLA absorbed was $45.8 \mu M$ in the cells treated by $c 9, t 11$-CLA isomer (Figure 5B) and $85.9 \mu \mathrm{M}$ in the cells treated by $\beta$-LG-CLA complex (Figure 5C).

\section{Antitumor Effects of $\beta$-LG-CLA Complex on Colon Cancer Cells}

The antitumor effect of $\beta$-LG-CLA complex on colon cancer cells was expressed according to Caco- 2 cell viability by methyl thiazolyl tetrazolium assay. Caco-2 cell viability was significantly inhibited in a time-dependent manner by $\beta$-LG-CLA complex (Figure 6). In the present experimental conditions, ethanol involved in the culture media influenced cell viability slightly. Treatment with $100 \mu M c 9, t 11$-CLA isomer showed a very low inhibitory effect on colon cancer cells within 24,48 , and $72 \mathrm{~h}$, and the inhibitory rate varied little. Under the treatment of bovine $\beta$-LG loading $100 \mu M$ $c 9, t 11$-CLA, the inhibition rate was $26.02 \pm 0.31 \%$ at $24 \mathrm{~h}, 49.09 \pm 0.01 \%$ at $48 \mathrm{~h}$, and $61.89 \pm 0.02 \%$ at 72 h compared with the control.

\section{DISCUSSION}

Bovine $\beta$-LG has been studied extensively over the past 60 years. Since the discovery of the retinol- $\beta$-LG complex by Futterman and Heller (1972), many methods have been used to observe the properties and structure of $\beta$-LG for binding hydrophobic ligands (Pérez and Calvo, 1995; Wu et al., 1999; Kontopidis et al., 2004; Konuma et al., 2007). As a major member of the lipocalin family, $\beta-\mathrm{LG}$ has a main ligand-binding site formed by a calyx. At least 2 other distinct binding sites exist per monomer for a variety of ligands: one is in a crevice near the $\alpha$-helix on the external surface of the $\beta$-barrel (Kontopidis et al., 2004), and another possible binding site was suggested to be located at the dimer interface (Harvey et al., 2007). In our research, we measured the binding-induced quenching of the intrinsic Trp 19 fluorescence of $\beta$-LG to estimate the binding constant. The result showed that $2.46 \mathrm{~mol}$ of $c 9, t 11$-CLA were bound per mole of $\beta-\mathrm{LG}$, which might be due to the 2 other binding sites just mentioned (Kontopidis et al., 2004; Harvey et al., 2007) being saturated simultaneously or before $c 9, t 11$-CLA binding with Trp 19 . The binding constant of $\beta$-LG-CLA complex is $3.7 \times 10^{6}$ $M^{-1}$, which is not as high as the binding of linoleic acid $\left(5.26 \times 106 M^{-1}\right.$; Frapin et al., 1993) but higher than $6.75 \times 10^{5} M^{-1}$ for docosahexaenoic acid (DHA) (Zimet and Livney, 2009). This might be because the smaller size and straighter structure of CLA can fit well into protein binding sites.

The $\beta$-LG-CLA complex we successfully synthesized is a micro-grade compound, with a particle size of 170.7 $\pm 0.08 \mathrm{~nm}$. To study the stability of $\beta$-LG-CLA complex in gastrointestinal conditions, we used a zeta potential test under $\mathrm{pH}$ ranging from 1.0 to 8.0 and a digestive enzymes hydrolysis experiment with pepsin and trypsin. Suspensions with zeta potential values more negative than $-40 \mathrm{mV}$ generally have good stability (ASTM, 1985). In our study, zeta potential values of $\beta$-LG-CLA complex were more negative than $-40 \mathrm{mV}$ in colon $\mathrm{pH}$ conditions ( $\mathrm{pH} 6.0$ to $\sim 7.4$ ). In gastric $\mathrm{pH}$ conditions (pH 1.0 to 3.0), the potential value was decreased to less positive than $40 \mathrm{mV}$. At physiological $\mathrm{pH}, \beta-\mathrm{LG}$ mostly exists as dimers; at $\mathrm{pH}$ below 3.5 and above 7.5 , the 

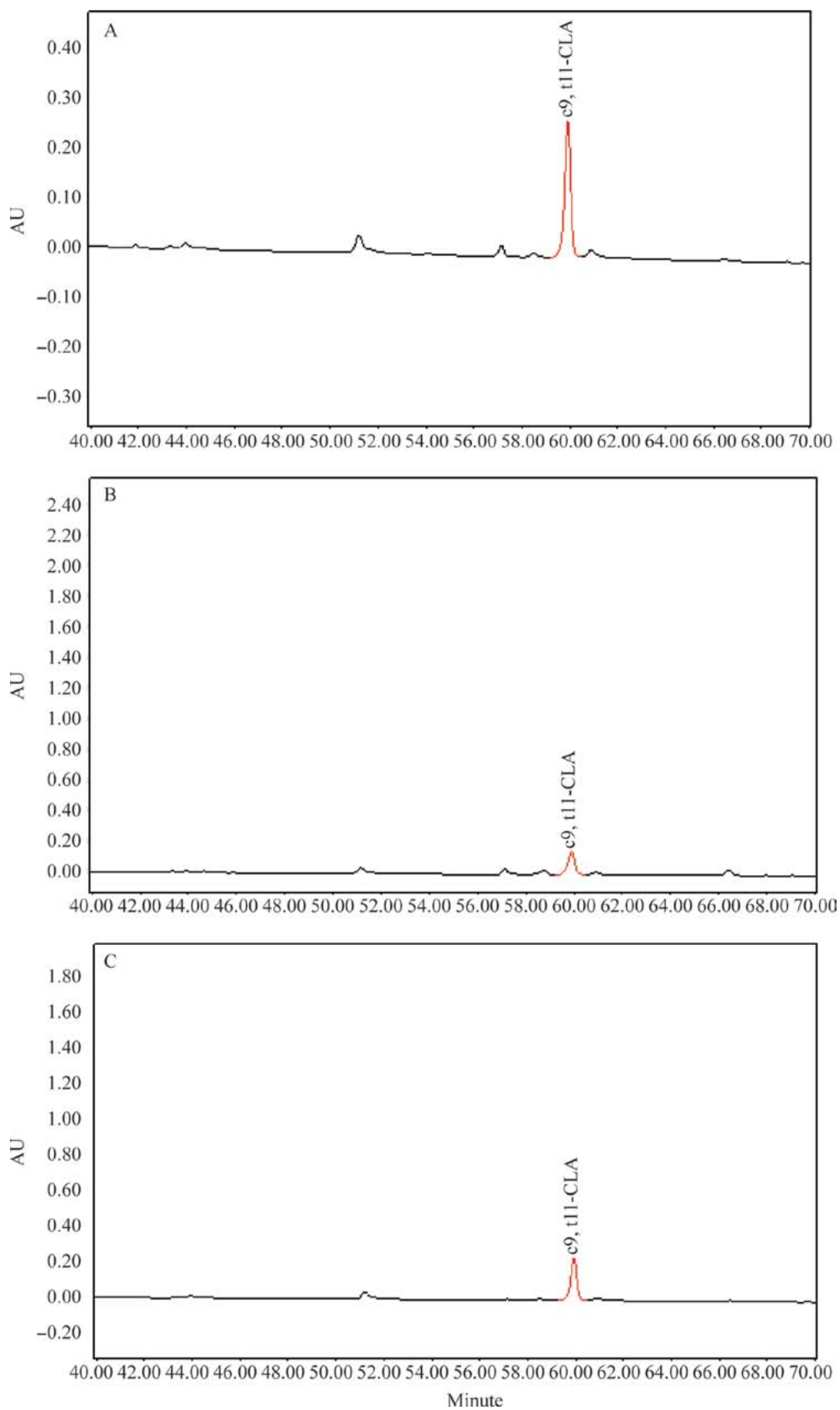

Figure 5. Chromatographic profiles of cis-9, trans-11 conjugated linoleic acid ( $c 9, t 11$-CLA) from Caco-2 cells. A) The 100- $\mu M$ standard $c 9, t 11$-CLA; B) the level of $c 9, t 11$-CLA absorbed in the cells treated by $c 9, t 11$-CLA isomer; C) the level of $c 9, t 11$-CLA absorbed in the cells treated by $\beta-\mathrm{LG}$ binding CLA complex. AU = arbitrary units. Color version available in the online PDF. 


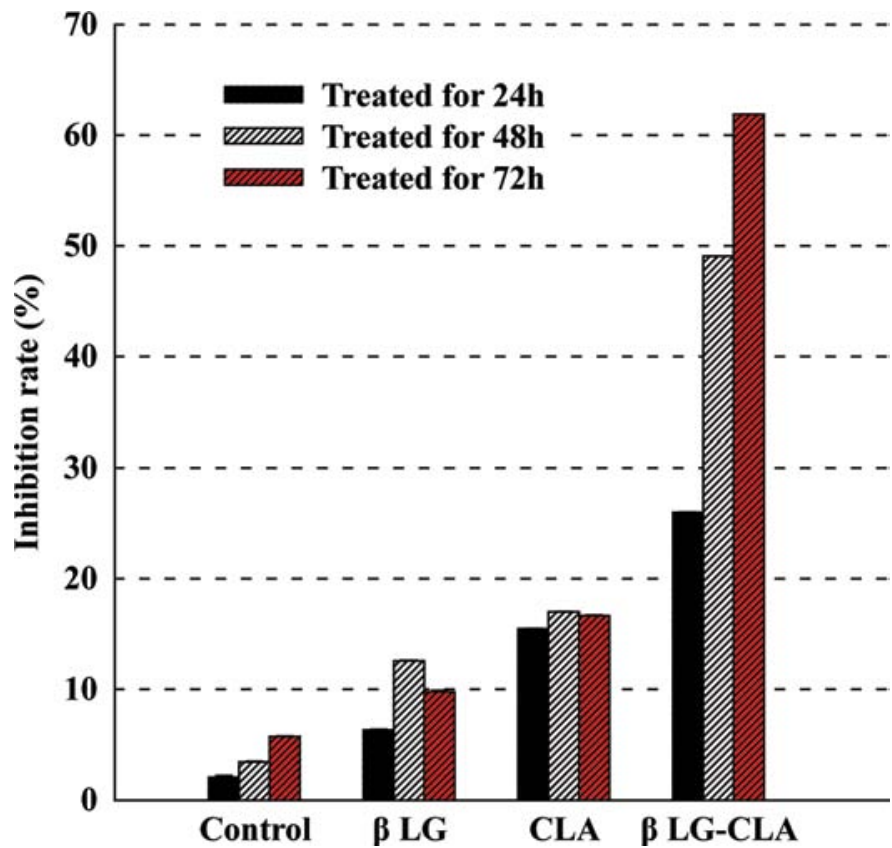

Figure 6. The inhibition effect of $\beta$-LG binding cis-9, trans-11 conjugated linoleic acid ( $\beta$-LG-CLA) complex on Caco-2 cells up to 72 h. Color version available in the online PDF.

protein dissociates into monomers (McKenzie, 1971), at which point $c 9, t 11$-CLA located at the dimer interface of $\beta$-LG would be released and influence the stability of $\beta$-LG-CLA complex in gastric conditions. However, at $\mathrm{pH}$ 8.0, the zeta potential value became more negative than $-40 \mathrm{mV}$, which might be because the structure of $\beta$-LG is still in the dimeric form at $\mathrm{pH} 8.4$ (Ragona et al., 2000). It has been said that $\beta-L G$ can resist peptic hydrolysis and remain stable and intact until reaching the upper portion of the small intestine (Chobert et al., 1995; Kiabatake and Kinekawa, 1998).

In our research, $\beta$-LG-CLA complex was digested by pepsin $(\mathrm{pH} 3.0)$ and trypsin $(\mathrm{pH}$ 8.0) for $2 \mathrm{~h}$, and the samples were withdrawn equally and adjusted to pH 7.0 before adding buffer loading to avoid abnormal migration in the SDS-PAGE. We found that $\beta$-LG-CLA complex was hydrolyzed slightly by both pepsin and trypsin. Although $\beta-\mathrm{LG}$ is a monomer $(18.4 \mathrm{kDa})$ at $\mathrm{pH}$ 3.0 and 8.0, the SDS-PAGE showed bands at $\sim 36 \mathrm{kDa}$, which might be associated with some $\beta$-LG changing to dimeric form at $\mathrm{pH}$ 7.0. It is worth mentioning that the intensity of the band at $\sim 36 \mathrm{kDa}$ of $\beta$-LG-CLA complex treated by trypsin was increased with extended time, which was also found in the antioxidant study of bovine milk $\beta$-LG by Liu et al. (2007). Considine et al. (2007) used $\beta$-LG type B to bind with $c 9, t 11$-CLA but merely studied the influence of heat and high pressure on the stability of the complex. Our research offers a new perspective by studying the stability of $\beta$-LG-CLA complex in gastric intestinal conditions. In nuclear magnetic resonance spectroscopy research on bovine $\beta-\mathrm{LG}$ binding with palmitic acid, it was reported that the release of palmitic acid starts at $\mathrm{pH}$ lower than 6.0 and is nearly complete at acidic $\mathrm{pH}$, which suggests $\beta$-LG cannot be used as a carrier through the alimentary tract for purposes of nutrition (Ragona et al., 2000). In the present research, $\beta$-LG-CLA complex was kept in Tween 40 to maintain a micelle state; although the stability of the complex is not very good in low $\mathrm{pH}$ conditions, we cannot confirm the binding extent of $c 9, t 11$-CLA when Tween 40 is present. The release dynamics of CLA from $\beta$-LG-CLA complex will be observed in a future study.

For the study of intestinal absorption of $c 9, t 11-\mathrm{CLA}$ from $\beta$-LG-CLA complex, RP-HPLC was used to show $c 9$, t11-CLA uptake in Caco-2 cells. We found that the concentration of $c 9, t 11$-CLA in Caco- 2 cells treated by $\beta$-LG-CLA complex was significantly greater than in those treated by $c 9, t 11$-CLA isomer. This could have 2 explanations. One explanation is that bovine $\beta-\mathrm{LG}$ has the ability to cross the Caco-2 cell monolayer membrane (Bernasconi et al., 2006); the other is that, as a member of the lipocalin family, bovine $\beta-L G$ has specific membrane receptors for transcellular transport, such as cytoplasmic celluar retino-binding protein and human STRA6 protein (Sundaram et al., 1999; Kawaguchi et al., 2007). Although vitamin-A-binding $\beta$-LG is a classic model for the character study of lipocalin family members, whether the membrane receptors can recognize other hydrophobic ligands still needs to be demonstrated.

High incidence rate of colorectal cancer is most likely due to high dietary intake of red or processed meat (Center et al., 2009). It is noteworthy that CLA, a mixture of positional and geometric isomers of LA found mainly in dairy and meats (Parodi, 1997), has been extensively studied both in vivo and in vitro as a possible anticarcinogen. In ruminant meat and dairy products, $c 9, t 11-\mathrm{CLA}$ is the major component of CLA isomers; thus, there have been recent assessments of whether $c 9, t 11$-CLA is more potent than other isomers for commercial CLA preparations. It has been reported that $c 9, t 11-\mathrm{CLA}$ is more potent than $t 10, c 12$-CLA in inhibiting the growth of colon cancer cell lines (Palombo et al., 2002). In our study, 100- $\mu M$ CLA binding $\beta-L G$ had the ability to inhibit Caco-2 cell growth in a time-dependent manner, but the 100- $\mu M$ CLA isomer had very little inhibitory effect on cell proliferation. This can be explained by the fact that culture conditions including the concentration of CLA, duration of the treatment, and the cell lines used seem to determine whether CLA isomers will affect cell growth. Yamasaki et al. (2002) reported that CLA at $10 \mu M$ 
did not affect cell growth in the presence of 5 or $10 \%$ fetal bovine serum; fatty acids can form a complex with bovine albumin (Beppu et al., 2006). The present study demonstrated the greater inhibitory effect of $\beta$-LGCLA complex compared with $c 9, t 11$-CLA isomer on the growth of human colon cancer cells.

\section{CONCLUSIONS}

In the present study, a microsized $\beta$-LG-CLA selfassembled complex, with mean particle size of 170.07 $\pm 0.08 \mathrm{~nm}$, was synthesized. The binding constant of $c 9, t 11$-CLA to bovine $\beta$-LG was also presented as $\mathrm{K}_{\mathrm{b}}=$ $3.7 \times 10^{6} M^{-1}$. The complex stored in Tween 40 showed very good stability at intestinal $\mathrm{pH}$ conditions and was hydrolyzed very little by digestive enzymes. However, the stability of $\beta$-LG-CLA complex was not good in gastric $\mathrm{pH}$ conditions. The release dynamics of CLA from $\beta$-LG-CLA complex in gastrointestinal conditions needs to be studied and will be observed in a future study. With the in vitro intestinal model with Caco-2 monomer in this study, we found that the extent of absorption of $c 9, t 11$-CLA in Caco- 2 cells was increased, which might be related to the lipocalin character of $\beta$-LG. The inhibition rate in colon cells is much greater with $\beta$-LG-CLA complex than with CLA isomers. More aspects still need to be observed to certify $\beta$-LG-CLA complex as a potential colon-targeted antitumor substance.

\section{ACKNOWLEDGMENT}

This work was supported by the National High Technology Research and Development Program of China (863 program), No. 2008AA10Z331.

\section{REFERENCES}

ASTM (American Society for Testing and Materials). 1985. Standard test methods for zeta potential of colloids in water and waste water. ASTM Standard D 4182-82. Annual Book of ASTM Standards. ASTM International, West Conshohocken, PA.

Beppu, F., M. Hosokawa, L. Tanaka, H. Kohno, T. Tanaka, and K. Miyashita. 2006. Potent inhibitory effect of trans9, trans 11 isomer of conjugated linoleic acid on the growth of human colon cancer cells. J. Nutr. Biochem. 17:830-836.

Bernasconi, E., R. Fritsché, and B. Corthésy. 2006. Specific effects of denaturation, hydrolysis and exposure to Lactococcus lactis on bovine $\beta$-lactoglobulin transepithelial transport, antigenicity and allergenicity. Clin. Exp. Allergy 36:803-814.

Brownlow, S., J. H. M. Cabral, R. Cooper, D. R. Flower, S. J. Yewdall, I. Polikarpov, A. C. T. North, and L. Sawyer. 1997. Bovine $\beta$-lactoglobulin at $1.8 \AA$ resolution-Still an enigmatic lipocalin. Structure 5:481-495.

Center, M. M., A. Jemal, R. A. Smith, and E. Ward. 2009. Worldwide variations in colorectal cancer. CA Cancer J. Clin. 59:366-378.

Chobert, J. M., L. Briand, V. Grinberg, and T. Haertlé. 1995. Impact of esterification on the folding and the susceptibility to peptic proteolysis of $\beta$-lactoglobulin. Biochim. Biophys. Acta 1248:170 176.
Christiaens, B., S. Symoens, S. Vanderheyden, Y. Engelborghs, A Joliot, and A. Prochiantz. 2002. Tryptophan fluorescence study of the interaction of penetratin peptides with model membranes. Eur. J. Biochem. 269:2918-2926.

Considine, T., H. A. Patel, H. Singh, and L. K. Creamer. 2007. Influence of binding conjugated linoleic acid and myristic acid on the heat- and high-pressure-induced unfolding and aggregation of $\beta$-lactoglobulin B. Food Chem. 102:1270-1280.

During, A., and E. H. Harrison. 2005. An in vitro model to study the intestinal absorption of carotenoids. Food Res. Int. 38:10011008 .

Flower, D. R. 1994. The lipocalin protein family: A role in cell regulation. FEBS Lett. 354:7-11.

Frapin, D., E. Dufour, and T. Haertle. 1993. Probing the fatty-acidbinding site of beta-lactoglobulins. J. Protein Chem. 12:443 449.

Futterman, S., and J. Heller. 1972. The enhancement of fluorescence and the decreased susceptibility to enzymatic oxidation of retinol complexed with bovine serum albumin, lactoglobulin and the retinol-binding protein of human plasma. J. Biol. Chem. 247:5168-5172.

Ha, Y. L., N. K. Grimm, and M. W. Pariza. 1987. Anticarcinogens from fried ground beef: Heat-altered derivatives of linoleic acid. Carcinogenesis 8:1881-1887.

Harvey, B. J., E. Bell, and L. Brancaleon. 2007. A tryptophan rotamer located in a polar environment probes $\mathrm{pH}$-dependent conformational changes in bovine $\beta$-lactoglobulin A. J. Phys. Chem. B 111:2610-2620.

Kawaguchi, R., J. Yu, J. Honda, J. Hu, J. Whitelegge, P. Ping, P. Wiita, D. Bok, and H. Sui. 2007. A membrane receptor for retinol binding protein mediates cellular uptake of vitamin A. Science 315:820-825.

Kay, J. K., T. R. Macle, M. J. Auldist, N. A. Thomson, and D. E. Bauman. 2004. Endogenous synthesis of cis-9, trans-11 conjugated linoleic acid in dairy cows fed fresh pasture. J. Dairy Sci. 87:369378.

Kelley, N. S., N. E. Hubbard, and K. L. Erickson. 2007. Conjugated linoleic acid isomers and cancer. J. Nutr. 137:2599-2607.

Kiabatake, N., and Y. I. Kinekawa. 1998. Digestibility of bovine milk whey protein and $\beta$-lactoglobulin in vitro and in vivo. J. Agric. Food Chem. 46:4917-4923.

Kontopidis, G., C. Holt, and L. Sawyer. 2004. $\beta$-Lactoglobulin: Binding properties, structure and function. J. Dairy Sci. 87:785-796.

Konuma, T., K. Sakurai, and Y. Goto. 2007. Promiscuous binding of ligands by $\beta$-lactoglobulin involves hydrophobic interactions and plasticity. J. Mol. Biol. 368:209-218.

Li, Z., T. Gu, B. Kelder, and J. J. Kopchick. 2001. Analysis of fatty acids in mouse cells using reversed-phase high-performance liquid chromatography. Chromatography A. 54:463-467.

Liu, H. C., W. L. Chen, and S. J. T. Mao. 2007. Antioxidant nature of bovine milk $\beta$-lactoglobulin. J. Dairy Sci. 90:547-555.

McKenzie H. A., 1971. $\beta$-Lactoglobulins. Pages 2257-2330 in Milk Proteins. H. A. McKenzie, ed. Academic Press Inc. Ltd., London, UK.

Palombo, J. D., A. Ganguly, B. R. Birstrian, and M. P. Menard. 2002. The antiproliferative effects of biologically active isomers of conjugated linoleic acid on human colorectal and prostatic cancer cells Cancer Lett. 177:163-172.

Papiz, M. Z., L. Sawyer, E. E. Eliopoulos, A. C. T. North, J. B C. Findlay, and R. Sivaprasadarao. 1986. The structure of $\beta$-lactoglobulin and its similarity to plasma retinol-binding protein. Nature 324:383-385.

Parkin. D. M., F. J. Bray, and P. Pisani. 2005. Global cancer statistics. 2002. CA Cancer J. Clin. 55:74-108.

Parodi, P. W. 1997. Cow's milk fat components as potential anticarcinogenic agents. J. Nutr. 127:1055-1060.

Pérez, M. D., and M. Calvo. 1995. Interaction of $\beta$-lactoglobulin with retinol and fatty acids and its role as a possible biological function for this protein: A review. J. Dairy Sci. 78:987-988.

Pervaiz, S., and K. Brew. 1985. Homology of $\beta$-lactoglobulin, serum retinol-binding protein and protein HC. Science 228:335-337. 
Ragona, L., F. Fogolari, L. Zetta, D. M. Pérez, P. Puyol, K. D. Kruif, F. Lôhr, H. Rũterjans, and H. Molinari. 2000. Bovine $\beta$-lactoglobulin: Interaction studies with palmitic acid. Protein Sci. 9:1347-1356.

Reddy, M., N. K. D. Kella, and J. E. Kinsella. 1998. Structural and conformational basis of the resistance of $\beta$-lactoglobulin to peptic and chymotryptic digestion. J. Agric. Food Chem. 36:737-741.

Sundaram, M., A. Sivaprasadarao, M. M. DeSousa, and J. B. C. Findlay. 1999. The transfer of retinol from serum retinol-binding protein to cellular retinol-binding protein is mediated by a membrane receptor. J. Biol. Chem. 273:3336-3342.

Wu, S. Y., M. D. Pérez, P. Puyol, and L. Sawyer. 1999. B-lactoglobulin binds palmitate within its central cavity. J. Biol. Chem. 274:170174 .
Yamasaki, M., H. Chujo, Y. Koga, A. Oishi, T. Rikimaru, M. Shimada, K. Sugimachi, H. Tachibana, and K. Yamada. 2002. Potent cytotoxic effect of the trans10, cis12 isomer of conjugated linoleic acid on rat hepatoma dRLh-84 cells. Cancer Lett. 188:171-180.

Zhao, X. L., K. X. Li, X. F. Zhao, and D. W. Chen. 2008. Study on colon-specific 5-Fu pH-enzyme Di-dependent chitosan microspheres. Chem. Pharm. Bull. (Tokyo) 56:963-968.

Zimet, P., and Y. D. Livney. 2009. Beta-lactoglobulin and its nanocomplexes with pectin as vehicles for $\omega-3$ polyunsaturated fatty acids. Food Hydrocoll. 23:1120-1126. 